\title{
Knowledge and Attitude of Student Nurses and Hospital Nurses regarding AIDS
}

\author{
Sanaa Mahmoud Ahmed Hassane \\ Lecturer of Pediatric Nursing, Faculty of Nursing,Minia University-Egypt
}

\begin{abstract}
:
Background: Amongst the health care professionals nurses and nursing student are an important component of the health care delivery system. Since they are the one who are responsible for the constant care of in-patient and thus, they come in close contact with blood and other body fluids of patients. Due to frequent and prolonged contact they are being identified as a potential risk group for the HIV/ AIDS spread.

Aim: The aim of this study was to assess knowledge andattitudes of student nurses andhospital nursesand to identify willingness to provide care for patients with AIDS. Adescriptive studydesign was used. The study was conducted at faculty of nursing, Minia University and in Minia University hospitals.A convenience sample of 84 student nurse and 46 working nurse were enrolled in this study.

Tool: Specially designedquestionnaire after reviewing the related literature. It consisted of three parts that include questions related to Socio-demographicdata;questions related student nurse and hospital nurse level of knowledge and questions related to attitude toward care of patient with AIDS.

Results: The present study indicate that the overall knowledge score was satisfactory for both student nurse and hospital nurse and 50\% of student nurse and 54.3\% of hospital nurse has negative attitude toward care of patient with AIDS.

Conclusion: It concluded that there is satisfactory level of knowledge and low attitude toward care of patient with AIDS.

Recommendation: It is recommended that continuing education programs are needed to increase awareness about AIDS risk factors, causes, clinical manifestation, prevention, complication and study on large number of student from more than faculty and hospital nurses from more hospitals. Also the nursing curriculum and teaching strategies need to be developed to address this health issue.
\end{abstract}

Keywords: Student Nurse, Hospital Nurse, Knowledge, Attitude, AIDS

\section{Introduction}

Human immunodeficiency virus / acquired immune deficiency syndrome (HIV/AIDS) hasbecome one of the significant public health problems in the world. AIDS is a fatal illness caused by a retro virus known as the HIV that breaks down body's immune system, leaving the person vulnerable to a host of life-threatening opportunistic infections, neurological disorder, and unusual malignancies (Park, 2013). Further, it affects the mental and social relationships of carriers and asymptomatic patients (Tavoosi et al., 2004).

AIDS (acquired immune deficiency syndrome) is the end-stage disease state characterized by severe damage to a person's immune system resulting from infection with HIV (human immunodeficiency virus). This immune system damage exposes an individual to a host of opportunistic infections, cancers, and other physical effects, such as significant weight loss. The underlying cause, HIV, is a blood-borne virus that is also present in sexual body fluids (semen, vaginal secretions) and breast milk (Patrick et al, 2007).

The number of Egyptians who died from HIV/AIDs doubled between 2005 and 2013, rising from 500 to 1,000, according to a new report from (National HIV Programme Situation and Gap Analysis Egypt 2015)

Egypt's first case of AIDS, or Acquired Immune Deficiency Syndrome, was detected in 1986. Since 1990 , the number of cases has climbed by $286 \%$, reaching around 14,000 cases in 2012, reported by (National HIV Programme Situation and Gap Analysis Egypt2015)

Egypt's death rate is one of the fastest rising in the region, but the country's AIDS-related deaths still only represent about $3 \%$ of total deaths in the Middle East and North Africa.

Across the MENA region, about 15,000 people died of AIDs-related causes in 2013, which is a $66 \%$ increase from 2005. In the region, 30\% of AIDS-related deaths occurred in Iran, $21 \%$ occurred in Sudan and $17 \%$ took place in Somalia.The ratio of male to female cases is 4:1. HIV/AIDS is most common among prisoners, street children, drug users and sex workers, according to ( UNICEF Annual Report 2015). More than $71 \%$ of the cases were transmitted through sexual intercourse, but the virus can also spread in other ways, including through blood transfusion and unhygienic cosmetology or dental work.

In Egypt, where 95\% of the population is Muslim and premarital sex is a taboo, families often look down on victims as "shameful", rather than being compassionate - even if the disease was not contracted through sexual 
intercourse, ( UNICEF Annual Report Egypt 2015) Instead of treating the patient, families may try to hide their "shame" by keeping their condition a secret until it's too late, or they may even get rid of their children, Still, less than $20 \%$ of infected Egyptians have access to treatment, UNAIDS reported.

A number of non-governmental organizations, such as UNAIDS, are cooperating with the Egyptian government to spread awareness about the disease and encourage voluntary laboratory tests for early detection. Every HIV positive patient is a potential candidate for disease transmission to the attending health care workers. So, the risk of accidental HIV in such cases, depend on their safe practice including universal precautions which in turn depends on their awareness and knowledge regarding the epidemiology of the disease. The accidental transmission of HIV infection to health care worker during occupational exposure is the real threats today (Kumar et al, 2002).

Amongst the health care professionals nurses and nursing student are an important component of the health care delivery system. Since they are the one who are responsible for the constant care of in-patient and thus, they come in close contact with blood and other body fluids of patients. Due to frequent and prolonged contact they are being identified as a potential risk group for the HIV/AIDS spread. To reduce the transmission, adequate knowledge about the disease and practice of safely measures are of great importance. Generating awareness regarding HIV/ AIDS in this group is crucial for AIDS management and prevention of HIV spread. (Goel et al., 2010)

Nurses play a major role in the care for HIV/AIDS patients and require current knowledge and skills to ensure that they are able to provide high quality, effective care to PLHIV and AIDS. Further, attitude of health workers in relation to HIV is and important determinant of their willingness to care to care and the quality of the care they will render to HIV patient. However, previous research identified discriminatory attitudes, misconceptions and lack of HIV knowledge among nurses toward patients with HIV and AIDS (Delobelle et al., 2009) .

Unfortunately, negative attitudes about HIV not only prevent health provider from delivering optimal healthcare but also decrease PLHIV's willingness to access healthcare.(Ding et al.,2005 and wong et al.,2004).

Among the health care professionals nurses and nursing students are an important component of the health care delivery system. Research indicates lack of knowledge lack of knowledge among nursing students Bektas and Kulakac (2007) and Tung et al (2008). However, majority of studies have shown that attitudes among nursing students toward people infected with HIV were generally positive. (Veeramah et al, (2008). Onthe other hand, few of the studies have indicate negative attitudes among nursing students toward HIV patients (Mahat and Eller 2009). Further, it is important to understand nursing students knowledge and attitudes toward PLHIVbecausethe educational preparation of nurses has been known to affect the attitude and the effectiveness of the care provided to PLHIV (Bektas and Kulakac 2007).

\section{Aim Of The Study}

This study aimed to assess knowledge and attitude of student nurse and hospital nurse regardingAIDS Research Questions

Is there a significant difference between nursing student and nurses from hospital in knowledge and attitude regarding AIDS?

\subsection{ResearchDesign:}

\section{Subjects And Methods}

A descriptive research design was utilized in this study.

\subsection{Setting:}

This study was conducted at Minia University Hospitalsform different departments, Minia University Hospital forObstetrics and Pediatrics (MUHOP)Kidney and Urology University Hospital andFaculty of Nursing Minia University.

4.3. Subjects:

A total of 84 nursing students in their $6^{\text {th }}$ semester "Third year student" faculty of nursing Minia University and 46 nurses working in Minia University hospitals were participated in the present study. Minia University hospitals

\subsection{Sample size:}

A convenient number of student and nurses from the previously mentioned settings.

\subsection{Tools for Data Collection:}

Tools for data collection was consisted of three tools: the researcher will be developed a tool

Tool I:A structured interview questionnairedesigned by the researcher after reviewing related literature and includes three parts:

Part (1):Include questions related to Socio-demographic data. As age, Gender, Number of siblings and rank. 
Part (2):Questions related student nurse and hospital nurse level of knowledge about AIDS which include 28 items.

Part (3):Questions related to attitude toward care of patient with AIDS which include 22 items.

\section{Scoring:}

For knowledge items, each item graded 2, it is considered satisfactory if the participant has score $>60 \%$ (33.6).

For attitude items which include 22 items according to Likert scale five items graded from strong agree1, agree 2 ,neutral agree 3 , do not agree4 and absolutely do not agree 5 . Positive attitude> 60\%(63 grade) while negative attitude $\square 60 \%$.

\subsection{Pilot Study}

After developing the tools, a pilot study was conducted on 5 hospital nurse and 9 student nurses. A pilot study was conducted for purpose of testing clarity, completeness, and to determine the time involvement. According to the results of pilot study, the needed omissions, and/or additions were done. Modification was done for some items of the questionnaire that was not consistent with this study.

\subsection{Ethical Consideration}

A written initial approval was obtained from the research ethical committee of the faculty of Nursing, Minia University. Oral informed consent was obtained from thestudent nurse and hospital nurse participate in this study. Each assessment sheet will be coded and student nameor hospital nurse not appeared on the sheets in the purpose of anonymity and confidentiality.

\subsection{Validity and Reliability}

The content validity of the data collection tool was examined by three experts who were affiliated to Faculty of Nursing, Minia and Assuit University at Pediatric Nursing Department. The tool was examined for content coverage, clarity, relevance, applicability, wording. Based on experts`comments and recommendations; minor modifications had been made such as rephrasing and rearrangements of some sentences.

Internal consistency was measured to identify the extent to which the items of tools measure the same concept and correlated with each other. Internal consistency estimate reliability by grouping questions in questionnaire that measure the same concept. Cronbach's alpha for reliability testing internal consistency was performed for each section of the structured interview questionnaire and the results was 0.75 and 0.72 for nurses' knowledge and attitude about AIDSrespectively.

\subsection{Procedure:}

This study was conducted during the academic year 2016 in the second semester. An official permission to conduct the study was done. The purpose of the study was explained to the study participant. The attitude questionnaire consists of five-point likert scale,with close ended questions. The instruction to fill the sheet was explained to the student nurse, the time needed to fill the questionnaire was 25 minute.Data was collected with the assistance of trained research assistant who works with me at the same department. The Questionnaires were shared and collected immediately and this facilitated $100 \%$ return rate. For hospital nurses I distribute the questionnaire through the head nurses and I explain to them the aim of study to them and we follow the return of 46 filled questionnaires only from total 85 nurse.

\section{Limitation of study:}

In our study we distribute questionnaire on 85 hospital nurses and 46 only of them who respond and return the questionnaire. This may because most of them are loaded and there is obvious shortage in nurses in Minia university hospitals.

\section{Results}

Table (1):relation between nursing students' and nurses from hospital as regard demographic characteristics ( $\mathrm{n}=$ 130)

\begin{tabular}{|c|c|c|c|c|c|c|}
\hline \multirow[t]{2}{*}{ Demographic characteristics } & \multicolumn{2}{|c|}{$\begin{array}{l}\text { Nursing student }(n= \\
84)\end{array}$} & \multicolumn{2}{|c|}{ Nurses from hospital $(n=46)$} & \multirow[t]{2}{*}{ t-test } & \multirow[t]{2}{*}{$\mathrm{P}$-value } \\
\hline & No. & $\%$ & No. & $\%$ & & \\
\hline \multicolumn{7}{|l|}{ Gender - } \\
\hline Male & 15 & 17.9 & 11 & 23.9 & \multirow[t]{2}{*}{$X^{2=} .681$} & \multirow{2}{*}{$\begin{array}{l}.409 \\
\text { NS }\end{array}$} \\
\hline Female & 69 & 82.1 & 35 & 76.1 & & \\
\hline \multicolumn{7}{|l|}{ Age } \\
\hline Mean \pm SD & \multicolumn{2}{|c|}{$21.3 \pm .79$ years } & \multicolumn{2}{|c|}{$30.5 \pm 6.4$ years } & 12.9 & $.000 *$ \\
\hline \multicolumn{7}{|l|}{ No. of siblings- } \\
\hline $1-$ & 71 & 84.5 & 39 & 84.8 & \multirow[t]{2}{*}{.349} & .969 \\
\hline $5-$ & 13 & 15.5 & 7 & 15.2 & & NS \\
\hline Mean \pm SD & \multicolumn{2}{|c|}{$3.9 \pm 1.4$} & \multicolumn{2}{|c|}{$3.8 \pm 1.4$} & & \\
\hline \multicolumn{7}{|l|}{ Rank - } \\
\hline $1-$ & 80 & 95.2 & 45 & 97.8 & \multirow[t]{2}{*}{.975} & .463 \\
\hline $5-$ & 4 & 4.8 & 1 & 2.2 & & NS \\
\hline Total & 84 & 100 & 46 & 100 & & \\
\hline Mean \pm SD & \multicolumn{2}{|c|}{$2.5 \pm 1.5$} & \multicolumn{2}{|c|}{$2.3 \pm 1.9$} & & \\
\hline
\end{tabular}

$\mathrm{NS}=$ not statistical significant difference. $\quad *$ Statistical significant difference at $\mathrm{p} \leq 0.05$ 
Table (1): illustrated that $82.1 \%$ of nursing student and $76.1 \%$ of hospital nurses participated in this study of them were female with mean age $21.3 \pm .79$ and $30.5 \pm 6.4$ years respectively. As regard mean no. of sibling were $3.9 \pm 1.4$ and $3.8 \pm 1.4$ among nursing students' and nurses from hospital respectively and ranking mean was $2.5 \pm 1.5$ and $2.3 \pm 1.9$ respectively with no statistically significance differences.

Table (2): relation between nursing students' and nurses from hospital as regard their knowledge about definition of AIDS $(n=130)$

\begin{tabular}{|c|c|c|c|c|c|c|}
\hline \multirow[t]{2}{*}{$\begin{array}{l}\text { Definition of } \\
\text { AIDS }\end{array}$} & \multicolumn{2}{|c|}{ Nursing student $(n=84)$} & \multicolumn{2}{|c|}{$\begin{array}{l}\text { Nurses from hospital }(n= \\
46)\end{array}$} & \multirow[t]{2}{*}{$\mathrm{X}^{2}$} & \multirow[t]{2}{*}{$\mathrm{P}-$ value } \\
\hline & No. & $\%$ & No. & $\%$ & & \\
\hline \multicolumn{5}{|c|}{ Is a disease that attacks the human immune system } & & \\
\hline Yes & 82 & 97.6 & 31 & 67.4 & \multirow{2}{*}{23.893} & \multirow[t]{2}{*}{$.000 *$} \\
\hline No & 2 & 2.4 & 15 & 32.6 & & \\
\hline \multicolumn{5}{|l|}{ Is a lethal disease } & & \\
\hline Yes & 61 & 72.6 & 26 & 56.5 & \multirow[t]{2}{*}{3.479} & \multirow{2}{*}{$\begin{array}{l}.062 \\
\mathrm{NS}\end{array}$} \\
\hline No & 23 & 27.4 & 20 & 43.5 & & \\
\hline
\end{tabular}

$\mathrm{NS}=$ not statistical significant difference.

* Statistical significant difference at $\mathrm{p} \leq 0.05$

Table (2) showed that $97.6 \%$ of nursing studentvs $67.4 \%$ nurses from hospitaldefined AIDS asa disease that attacks the human immune systemwith statistically significance difference. While $72.6 \%$ vs $56.5 \%$ defined it as a lethal disease with no statistically significance differences respectively.

Table 3: relation between nursing students' and nurses from hospital as regard their knowledge about risk factors of AIDS $(n=130)$

\begin{tabular}{|c|c|c|c|c|c|c|}
\hline \multirow[t]{2}{*}{ Risk factor } & \multicolumn{2}{|c|}{ Nursing student $(n=84)$} & \multicolumn{2}{|c|}{ Nurses from hospital $(n=46)$} & \multirow[t]{2}{*}{$\mathrm{X}^{2}$} & \multirow[t]{2}{*}{$\mathrm{P}$ - value } \\
\hline & No. & $\%$ & No. & $\%$ & & \\
\hline \multicolumn{7}{|c|}{ Intravenous drug abusers, those who practice unprotected sex and prostitutes } \\
\hline Yes & 74 & 88.1 & 42 & 91.3 & \multirow[t]{2}{*}{.319} & .572 \\
\hline No & 10 & 11.9 & 4 & 8.7 & & NS \\
\hline \multicolumn{7}{|c|}{ Increasing number of one's sexual partner } \\
\hline Yes & 66 & 78.6 & 24 & 52.2 & \multirow[t]{2}{*}{9.723} & \multirow[t]{2}{*}{$.002 *$} \\
\hline No & 18 & 21.4 & 22 & 47.8 & & \\
\hline \multicolumn{7}{|l|}{ Unsafe sex } \\
\hline Yes & 75 & 89.3 & 23 & 50.0 & \multirow[t]{2}{*}{24.721} & \multirow[t]{2}{*}{$.000 *$} \\
\hline No & 9 & 10.7 & 23 & 50.0 & & \\
\hline \multicolumn{7}{|c|}{ Mosquito bite } \\
\hline Yes & 58 & 69.0 & 29 & 63.0 & \multirow[t]{2}{*}{.484} & .487 \\
\hline No & 26 & 31.0 & 17 & 37.0 & & NS \\
\hline \multicolumn{7}{|c|}{ Needle sharing } \\
\hline Yes & 78 & 92.9 & 38 & 82.6 & \multirow[t]{2}{*}{3.249} & .07 \\
\hline No & 6 & 7.1 & 8 & 17.4 & & NS \\
\hline \multicolumn{7}{|c|}{ Public toilets } \\
\hline Yes & 57 & 67.9 & 33 & 71.7 & \multirow[t]{2}{*}{.210} & .647 \\
\hline No & 27 & 32.1 & 13 & 28.3 & & NS \\
\hline \multicolumn{7}{|c|}{ Blood transfusion } \\
\hline Yes & 74 & 88.1 & 38 & 82.6 & \multirow[t]{2}{*}{.750} & .386 \\
\hline No & 10 & 11.9 & 8 & 17.4 & & NS \\
\hline \multicolumn{7}{|c|}{ Kiss on cheek } \\
\hline Yes & 31 & 36.9 & 10 & 21.7 & \multirow[t]{2}{*}{3.166} & .07 \\
\hline No & 53 & 63.1 & 36 & 78.3 & & NS \\
\hline \multicolumn{7}{|c|}{ Breast feeding } \\
\hline Yes & 30 & 35.7 & 13 & 28.3 & \multirow[t]{2}{*}{.746} & .388 \\
\hline No & 54 & 64.3 & 33 & 71.1 & & NS \\
\hline \multicolumn{7}{|c|}{ Sharing glass } \\
\hline Yes & 34 & 40.5 & 8 & 17.4 & \multirow[t]{2}{*}{7.243} & \multirow[t]{2}{*}{$.007 *$} \\
\hline No & 50 & 59.5 & 38 & 82.6 & & \\
\hline Touching & & & & & & \\
\hline Yes & 30 & 35.7 & 22 & 47.8 & 1.817 & .178 \\
\hline No & 54 & 64.3 & 24 & 52.2 & & NS \\
\hline
\end{tabular}

$\mathrm{NS}=$ not statistical significant difference.

* Statistical significant difference at $\mathrm{p} \leq 0.05$

Table (3): presented that $89.3 \%$ nurse student and $50 \%$ of hospital nurses know that unsafe sex is a risk factor for AIDS followed by $78.6 \%$ of nurse student and $52.2 \%$ of hospital nurses know that increasing number of one's sexual partners then sharing glass is not a risk factors for AIDS (59.5\% vs 82.6\% respectively) with statistically significant difference which $\mathrm{p}$ - value $\leq .000, .002, \& 007$ respectively. 
Table 4: relation between nursing students' and nurses from hospital as regard their knowledge about causes of $\operatorname{AIDS}(\mathrm{n}=130)$

\begin{tabular}{|c|c|c|c|c|c|c|}
\hline \multirow[t]{2}{*}{ Causes } & \multicolumn{2}{|c|}{ Nursing student $(n=84)$} & \multicolumn{2}{|c|}{ Nurses from hospital $(n=46)$} & \multirow[t]{2}{*}{$\mathrm{X}^{2}$} & \multirow[t]{2}{*}{$\mathrm{P}$ - value } \\
\hline & No. & $\%$ & No. & $\%$ & & \\
\hline \multicolumn{7}{|c|}{ Sharing needle with a HIV positive } \\
\hline Yes & 72 & 85.7 & 24 & 52.2 & \multirow[t]{2}{*}{2.451} & \multirow[t]{2}{*}{$.000^{*}$} \\
\hline No & 12 & 14.3 & 22 & 47.8 & & \\
\hline \multicolumn{7}{|c|}{ Infect others without being ill themselves } \\
\hline Yes & 45 & 53.6 & 32 & 69.6 & \multirow[t]{2}{*}{3.149} & .07 \\
\hline No & 39 & 46.4 & 14 & 30.4 & & NS \\
\hline \multicolumn{7}{|c|}{ Is rather thought of a disease related to sexual risk behavior than as one related to sexual preferences } \\
\hline Yes & 67 & 79.8 & 40 & 87.0 & \multirow[t]{2}{*}{1.057} & .304 \\
\hline No & 17 & 20.2 & 6 & 13.0 & & NS \\
\hline \multicolumn{7}{|c|}{ Transmitted by blood and blood products } \\
\hline Yes & 79 & 94.0 & 43 & 93.5 & \multirow[t]{2}{*}{.017} & .897 \\
\hline No & 5 & 6.0 & 3 & 6.5 & & NS \\
\hline \multicolumn{7}{|c|}{ Can occur in both homosexual and heterosexual relationships } \\
\hline Yes & 73 & 86.9 & 42 & 91.3 & \multirow[t]{2}{*}{.564} & \multirow{2}{*}{$\begin{array}{l}.453 \\
\text { NS }\end{array}$} \\
\hline No & 11 & 13.1 & 4 & 8.7 & & \\
\hline
\end{tabular}

$\mathrm{NS}=$ not statistical significant difference.

* Statistical significant difference at $\mathrm{p} \leq 0.05$

Table (4): found that $85.7 \%$ of nurse student and $52.2 \%$ of hospital nurses identify sharing needle with a HIV positive is a cause of AIDS with statistically significant difference which $\mathrm{p}$ - value $\leq .000$, followed by it transmitted by blood and blood products (94\% vs 93.5 respectively) then AIDS occur in both homosexual and heterosexual relationships with $86.9 \%$ of nurse student and $91.3 \%$ of hospital nurses and $79.8 \%$ of nurse student and $87.0 \%$ of hospital nurses reported it is rather thought of a disease related to sexual risk behavior than as one related to sexual preferences with no statistically significant difference.

Table (5): relation between nursing students' and nurses from hospital as regard their knowledge about clinical manifestations of AIDS $(n=130)$

\begin{tabular}{|c|c|c|c|c|c|c|}
\hline \multirow[t]{2}{*}{ Manifestation } & \multicolumn{2}{|c|}{ Nursing student $(n=84)$} & \multicolumn{2}{|c|}{ Nurses from hospital $(n=46)$} & \multirow[t]{2}{*}{$\mathrm{X}^{2}$} & \multirow[t]{2}{*}{$\mathrm{P}$ - value } \\
\hline & No. & $\%$ & No. & $\%$ & & \\
\hline \multicolumn{7}{|c|}{ T -lymphocytes decrease } \\
\hline Yes & 54 & 64.3 & 37 & 80.4 & \multirow[t]{2}{*}{3.691} & \multirow[t]{2}{*}{$.05 *$} \\
\hline No & 30 & 35.7 & 9 & 19.6 & & \\
\hline \multicolumn{7}{|c|}{ Symptoms occur within six months following infection with HIV } \\
\hline Yes & 62 & 73.8 & 34 & 73.9 & \multirow[t]{2}{*}{.000} & \multirow{2}{*}{$\begin{array}{l}.990 \\
\text { NS }\end{array}$} \\
\hline No & 22 & 26.2 & 12 & 26.1 & & \\
\hline
\end{tabular}

$\mathrm{NS}=$ not statistical significant difference.

* Statistical significant difference at $\mathrm{p} \leq 0.05$

Table (5): showed that $73.8 \%$ of nurse student and $73.9 \%$ of hospital nurses reported symptoms occur within six months following infection with HIV and T -lymphocytes decrease when person infected with AIDS with $64.3 \%$ of nurse student vs $80.4 \%$ of hospital nurses with statistically significant difference which p - value $\leq .05$

Table (6): relation between nursing students' and nurses from hospital as regard their knowledge about therapeutic management of AIDS $(n=130)$

\begin{tabular}{|c|c|c|c|c|c|c|}
\hline \multirow[t]{2}{*}{ Management } & \multicolumn{2}{|c|}{ Nursing student $(n=84)$} & \multicolumn{2}{|c|}{ Nurses from hospital $(n=46)$} & \multirow[t]{2}{*}{$\mathrm{X}^{2}$} & \multirow[t]{2}{*}{$\mathrm{P}-$ value } \\
\hline & No. & $\%$ & No. & $\%$ & & \\
\hline \multicolumn{7}{|l|}{ No cure } \\
\hline Yes & 58 & 69.0 & 40 & 87.0 & \multirow[t]{2}{*}{5.137} & \multirow[t]{2}{*}{$.02 *$} \\
\hline No & 26 & 31.0 & 6 & 13.0 & & \\
\hline \multicolumn{7}{|l|}{ Isolation } \\
\hline Yes & 69 & 82.1 & 29 & 63.0 & \multirow[t]{2}{*}{5.843} & \multirow[t]{2}{*}{$.02 *$} \\
\hline No & 15 & 17.9 & 17 & 37.0 & & \\
\hline
\end{tabular}

* Statistical significant difference at $\mathrm{p} \leq 0.05$

Table (6): found that $69.0 \%$ of nurse student and $87.0 \%$ of hospital nurses reported no cure for person infected with HIV and isolation is most suitable management for it with $82.1 \%$ of nurse student vs $63.0 \%$ of hospital nurses with statistically significant difference which $\mathrm{p}$ - value $\leq .02 \& .02$ respectively 
Table 7: relation between nursing students' and nurses from hospital as regard their knowledge about prevention of AIDS $(\mathrm{n}=130)$

\begin{tabular}{|c|c|c|c|c|c|c|}
\hline \multirow[t]{2}{*}{ Prevention } & \multicolumn{2}{|c|}{ Nursing student $(\mathrm{n}=84)$} & \multicolumn{2}{|c|}{ Nurses from hospital $(n=46)$} & \multirow[t]{2}{*}{$\mathrm{X}^{2}$} & \multirow[t]{2}{*}{$\mathrm{P}-$ value } \\
\hline & No. & $\%$ & No. & $\%$ & & \\
\hline \multicolumn{7}{|c|}{ Using condom } \\
\hline Yes & 71 & 84.5 & 26 & 56.5 & \multirow[t]{2}{*}{12.305} & \multirow[t]{2}{*}{$.000 *$} \\
\hline No & 13 & 15.5 & 20 & 43.5 & & \\
\hline \multicolumn{7}{|c|}{ Using blood precautions } \\
\hline Yes & 80 & 95.2 & 26 & 56.5 & \multirow[t]{2}{*}{29.597} & \multirow[t]{2}{*}{$.000^{*}$} \\
\hline No & 4 & 4.8 & 20 & 43.5 & & \\
\hline \multicolumn{7}{|c|}{ Wear eye protection } \\
\hline Yes & 71 & 84.5 & 30 & 65.2 & \multirow[t]{2}{*}{6.392} & \multirow[t]{2}{*}{$.01 *$} \\
\hline No & 13 & 15.5 & 16 & 34.8 & & \\
\hline
\end{tabular}

* Statistical significant difference at $\mathrm{p} \leq 0.05$

Table (7): showed that,95.2\% of Nursing student and 56.5\% Nurses from hospital reported using blood precautions can prevent AIDS occurrence, followed by using condom, then wear eye protection with $84.5 \%$ Nursing student and 56.5\% Nurses from hospital and $84.5 \%$ of Nursing student and $65.2 \%$ Nurses from hospital respectively with statistically significant difference which $\mathrm{p}$ - value $\leq .000, .000 \& .01$ respectively

Table 8: relation between nursing students' and nurses from hospital as regard their knowledge about complications of AIDS ( $\mathrm{n}=130)$

\begin{tabular}{|c|c|c|c|c|c|c|}
\hline \multirow[t]{2}{*}{ Complications } & \multicolumn{2}{|c|}{ Nursing student $(n=84)$} & \multicolumn{2}{|c|}{ Nurses from hospital $(n=46)$} & \multirow{3}{*}{$X^{2}$} & \multirow{3}{*}{$P$ - value } \\
\hline & No. & $\%$ & No. & $\%$ & & \\
\hline \multicolumn{5}{|c|}{ Infection (opportunistic) } & & \\
\hline Yes & 72 & 85.7 & 37 & 80.4 & \multirow[t]{2}{*}{.612} & .434 \\
\hline No & 12 & 14.3 & 9 & 19.6 & & NS \\
\hline \multicolumn{7}{|l|}{ Kaposi sarcoma } \\
\hline Yes & 54 & 64.3 & 27 & 58.7 & \multirow[t]{2}{*}{.395} & .573 \\
\hline No & 30 & 35.7 & 19 & 41.3 & & NS \\
\hline \multicolumn{7}{|l|}{ Death } \\
\hline Yes & 67 & 79.8 & 38 & 82.6 & \multirow[t]{2}{*}{.155} & \multirow{2}{*}{$\begin{array}{l}.694 \\
\text { NS }\end{array}$} \\
\hline No & 17 & 20.2 & 8 & 17.4 & & \\
\hline
\end{tabular}

$\mathrm{NS}=$ not statistical significant difference.

Table (8): presented that $85.7 \%$ of nursing student and $80.4 \%$ of nurse from hospital know that Infection (opportunistic) is complication of AIDS while $79.8 \%$ Nursing student and $82.6 \%$ of Nurses from hospital know AIDS is the evitable end of patient with AIDS and 64.3\% Nursing student and 58.7\% Nurses from hospital also Kaposi sarcoma is a complication of it.

Table (9): relation between nursing students' and nurses from hospital as regard their attitude regarding AIDS $(\mathrm{n}=130)$

\begin{tabular}{|l|l|l|l|l|l|l|}
\hline \multirow{2}{*}{ Level of attitude } & \multicolumn{2}{|l|}{$\begin{array}{l}\text { Nursing student }(\mathrm{n}= \\
84)\end{array}$} & \multicolumn{2}{l|}{ Nurses from hospital $(\mathrm{n}=46)$} & $\mathrm{X}^{2}$ & $\mathrm{P}-$ value \\
\cline { 2 - 6 } & No. & $\%$ & No. & $\%$ & \\
\hline Positive attitude $(>60 \%(>63$ score $)$ & 42 & 50.0 & 21 & 45.7 & .225 & .635 \\
\hline Negative $(\leq 60 \%(\leq 63$ score $)$ & 42 & 50.0 & 25 & 54.3 & & NS \\
\hline
\end{tabular}

$\mathrm{NS}=$ not statistical significant difference.

Table (9): showed that 50\% of nursing student and 54.3\%of nurses from hospital have negative attitude toward care of patient with AIDS with no significance difference.

Table (10): Correlation between knowledge of nursing students' and nurses from hospital as regard their demographic data $(n=130)$

\begin{tabular}{|c|c|c|c|c|}
\hline \multirow[t]{3}{*}{ Demographic data } & \multicolumn{4}{|c|}{ Knowledge level } \\
\hline & \multicolumn{2}{|c|}{ Nursing student } & \multicolumn{2}{|c|}{ Nurses from hospital } \\
\hline & $\mathrm{r}$ & $\mathrm{p}$ & $\mathrm{R}$ & $\mathrm{P}$ \\
\hline Age & .111 & .315 & .427 & $.003 * *$ \\
\hline Gender & .063 & .568 & .166 & .270 \\
\hline No. of sister & .004 & .972 & .088 & .563 \\
\hline Rank of individual & .000 & .999 & .103 & .498 \\
\hline Attitude & .010 & .931 & .799 & $.000 * *$ \\
\hline
\end{tabular}

**Correlation is significant at the 0.01 level (2-tailed). 
Table (10) presented a high association between knowledge of nurses from hospital and their attitude toward patients' care with AIDS which $r=.799 \& \mathrm{p}$ - value $\leq .000$ and fair association between knowledge of nurses from hospital and their age which $\mathrm{r}=.427 \& \mathrm{p}$ - value $\leq .003$

Reliability of knowledge .750 and attitude .720

\section{Discussion}

Nurses play a critical role in caring for persons living with HIV/AIDS. Inadequate care and discrimination due to negative attitudes of nurses caring for persons living with HIV/AIDS . There is a need to advocate for appropriate HIV/AIDS awareness raising campaigns in nurses to reduce the gaps in knowledge and decrease stigmatizing attitudes towards people living with HIV/AIDS (Haroun et al., 2016 and Okpalaet al., 2017)

The present study aimed to assess knowledge and attitude of student nurse and hospital nurse regarding AIDSRegarding relation between nursing students and nurses from hospital and their knowledge about definition and risk factors of AIDS, the results of this study showed that, most of nursing studentversus only around half of nurses from hospital had satisfactory knowledge regarding definition and risk factors of AIDS with statistically significance difference. This information gap between nursing studentand nurses from hospital may be due to recent knowledge stockpiled among the nursing student from teaching courses during the faculty study. Contrary nurses from hospital who did not had enough theoretical knowledge about the disease or not covered during their study years. Unlike our interpretation (Marranzano et al., 2013) they found in their study that no association between level of knowledge and attendance to HIV lectures, courses or workshops. Another finding of a South African study by (Juan 2004) which found poor knowledge of HIV/AIDS among Nurses. Contradicts the findings of study in South East, Nigeria which found the majority of the respondents had good knowledge of HIV/AIDS (Okpalaet al., 2017).

On another hand and in conclusion of study by (Al-Rabeei et al., 2012) about knowledge, attitude and beliefs towards HIV/AIDS among students of health institutes in Sana'a city, which reviled there was a moderate level of knowledge among students in Sana'a health institutes.

In same context and when we looked at the remaining items about knowledge as causes, clinical manifestations, prevention and complications of AIDS, the results of this study reviled that level of knowledge among nursing students' versus nurses from hospitalwas fluctuated, between increase level of nursing students' knowledge in some items and increase level of nurses from hospital' knowledge in another items.

Generally, the level of knowledge for both group ranged from unsatisfactory to satisfactory. This is a serious indicator because normally the level of knowledge about this issue in both group should be remain satisfactory to all items. These results underline the need to strengthen education on all aspects of HIV/AIDS to improve knowledge of hospital nurses and nursing students.

The results of previous study was conducted by (Bekta $\square$ and Kulakaç 2007)on 227 nursing students from the School of Health in Antalya, Turkey about Knowledge and attitudes of nursing students toward patients living with HIV/AIDS (PLHIV): a Turkish perspective and reviled that the majority of nursing students in this study had a moderate level of HIV/AIDS knowledge. Another study conducted by (Premadasa et al., 2015) which about Knowledge of and attitudes towards HIV/AIDS: a survey among dental students in Ajman, UAE.This study showed that the median score for students' overall knowledge was $39.5 \%$. A study (He L 2016) concluded that integrated educational interventions enhance nurses' knowledge of risk reduction for occupationally acquired HIV infections and improve the observance of universal precautionary procedures. This enhancement allows nurses to assume a teaching role for prevention and management of HIV/AIDS.

Another section in this study was about relation between nursing students' and nurses from hospital and their attitude toward AIDS .The results explored that around half of both nursing student and nurses from hospital have negative attitude toward care of patient with AIDS with no significance difference.

In the same line the finding of study by ( Röndahl et al., 2003) who reported that both the nursing staff and the nursing students expressed empathic attitudes towards HIV-infected and homosexual HIV-infected patients.

Another study by (Khan et al., 2017), who concluded that, dental students' ethical beliefs about HIV/AIDS were not consistent with the ethical principles as stated in the code of ethics and they held negative attitudes towards HIV/AIDS . It is important to adopt strategies to improve the empathic tendencies and attitudes of nursing students

Regarding the correlation between knowledge of nursing students' and nurses from hospital with their demographic data, this study presented that a high association between knowledge of nurses from hospital and their attitude toward patients' care with AIDS and fair association between knowledge of nurses from hospital and their age. In the same line (Pickles et al., 2012 ) presented that, no statistically significant differences were found in attitude score based on participants' age, gender, previous HIV/AIDS education, previous nursing experience or previous experience of caring for someone with HIV/AIDS.A study conducted 
by (Suominen etal., 2010) about and Nurses' knowledge and attitudes to HIV/AIDS an international comparison between Finland, Estonia and Lithuania and reported that , factors positively influencing levels of knowledge and attitudes were education, previous experience of providing care to HIV/AIDS patient or knowing someone with the infection, and willingness to provide care to HIV/AIDS patients. Another study by (Pickles et al, 2012) about undergraduate nursing student's attitudes toward caring for people with HIV/AIDS and reviled that No statistically significant differences were found in attitude score based on participants' age, gender, previous HIV/AIDS education, previous nursing experience or previous experience of caring for someone with HIV/AIDS.

\section{Conclusion And Recommendations}

It concluded that there is satisfactory level of knowledge and low attitude toward care of patient with AIDS.Little is recommended that continuing education programs are needed to increase awareness about AIDS risk factors, causes, clinical manifestation, prevention, complication and study on large number of student from more than faculty and hospital nurses from more hospital. Also the nursing curriculum and teaching strategies need to be developed to address this health issue.

\section{References}

[1]. Al-Rabeei N.A, Dallak A.M, and Al-Awadi F.G (2012): Knowledge, attitude and beliefs towards HIV/AIDS among students of health institutes in Sana'a city EMHJ • Vol. 18 No. 3

[2]. Bekta $\square$ HA1, Kulakaç O. (2007): Knowledge and attitudes of nursing students toward patients living with HIV/AIDS (PLHIV): a Turkish perspective. AIDS Care.Aug; 19(7):888-94

[3]. Delobelle P, Rawlinson J L, Ntuli S, Malatsi I, Decock R, and Depoorter A M. (2009): Knowledge, attitudes, practice and perceptions of rural nurses in south rural nurses in South Africa $\mathbf{J}$ Adv Nurs;

[4]. Ding L, Landon B E, Wilson I B, Wong M D, Shapiro M F, Cleary P D, (2005):Predictors and consequences of negative physician attitudes toward HIV- infected injections drug users. Arch Intern Med 2005; 165:618-23.

[5]. Goel N K, Bansal R, Pathak R, Sharma H K, Aggrarwal M and Luthra S C ( 2010):Knowledge and awareness of nursing students about HIV/ AIDS. Health and population perspectives and issues Vol. 33(1), 55-60.

[6]. He L, Lu Z, Huang J, Zhou Y, Huang J, Bi Y, Li J (2016): An Integrated Intervention for Increasing Clinical Nurses' Knowledge of HIV/AIDS-Related Occupational Safety. Int J Environ Res Public Health. Nov 7;13(11).

[7]. Haroun D., El Saleh O., Wood L., Mechli R., Al Marzouqi N.,and Anouti S.( 2016): Assessing Knowledge of, and Attitudes to, HIV/AIDS among University Students in the United Arab Emirates, PLOS ONE | DOI:10.1371/journal.pone.0149920 February 25.

[8]. Khan SA, Liew ML, Omar H, (2017): Role of ethical beliefs and attitudes of dental students in providing care for HIV/AIDS patients. Saudi Dent J. Jan; 29(1):7-14.

[9]. Pickles D, King L, Belan I, ( 2012): Undergraduate nursing student,s attitudes towards caring for people with HIV/AIDSNurse Educ Today. Jan;32(1):15-20.

[10]. Okpala P.U, Rebecca , Nwaneri A.C, Onyiapat J., Emesowum A., Osuala E.O., and Adeyemo F.O (2017): Nurses' knowledge and attitude to the care of HIV/AIDS patients in South East, Nigeria Int J Community Med Public Health. 2017 Feb;4(2):547-553

[11]. Röndahl G1, Innala S, Carlsson M, ( 2003):Nursing staff and nursing students' attitudes towards HIV-infected and homosexual HIV-infected patients in Sweden and the wish to refrain from nursing. J Adv Nurs. Mar;41(5):454-61.

[12]. Suominen T ${ }^{1}$, Koponen N, Mockiene V, Raid U, Istomina N, Vänskä ML,

[13]. Premadasa G1, Sadek M, Ellepola A, Sreedharan J, Muttappallymyalil J. (2015): Knowledge of and attitudes towards HIV/AIDS: a survey among dental students in Ajman, UAE. J Investig Clin Dent. May;6(2):147-55.

[14]. Marranzano M., Ragusa R., Platania M., Faro G. , and Coniglio M.A (2013): Knowledge, attitudes and practices towards patients with HIV/AIDS in staff nurses in one university hospital in Sicily, Epidemiology Biostatistics and Public Health, Volume 10 , Number 1

[15]. National HIV Programme Situation and Gap Analysis Egypt 2015

[16]. Juan CW, Siebers R, Wu FF, Wu CJ, Chang YJ, Chao C.( 2004): The attitudes, concerns, gloving practices and knowledge of nurses in a Taiwanese hospital regarding AIDS and HIV. Int J Nurs Pract. 10(1):32-8.

[17]. Mahat G, and Eller L S, (2009): HIV/AIDSand universal precautions: Knowledge and attitudes of Nepalese nursing students. J Adv Nurs;65:1907-15.

[18]. National HIV Programme Situation and Gap Analysis Egypt 2015)

[19]. Park K (2013): Epidemiology of Communicable Disease. Park's Textbook of Preventive and Social Medicine 22 ${ }^{\text {nd }}$ ed. Jabalpur; M/s Bhannot Publishers; p. 316-28.

[20]. Patrick D L, Murray T P,Bigby J N and Auerbach J (2007): An Added Burden: The Impact of the HIV/AIDS Epidemic on Communitiesof Color in Massachusetts. Massachusetts Department of Public HealthHIV/AIDS Bureau.HIV/AIDS Bureau Kevin Cranston, Director World AIDS Day December 1,.

[21]. Tung W C, Ding K, Farmer S, (2008):Knowledge, attitude and behaviors related to HIV and AIDS among college students in Taiwan, J Assoc Nurses AIDS Care; 19: 397-408.

[22]. Tavoosi A, Zaferani A, Enzevaei A, Tajik P, Ahmadinezhad Z, (2004): Knowledge and attitude toward HIV/AIDS among Iranian students, BMC Public Health. 4:17.

[23]. UNICEF Annual Report 2015

[24]. Veeramah V, Bruneau B, and McNaught A, (2008): Exploring Knowledge and skills on HIV in student nurses and midwives. Br j Nurs; $17: 186-91$. 